Lebedev, S.V. (2021). Cultural heritage protection in the globalization context. The Collection of Mini Monographs. Klironomy, 2 (2), 7-26. Hlučín-Bobrovníky: “Anisiia Tomanek” OSVČ.

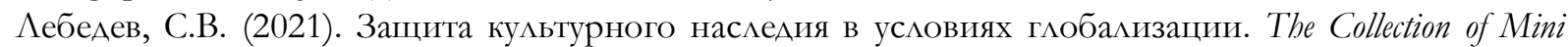
Monographs. Klironomy, 2 (2), 7-26. Hlučín-Bobrovníky: “Anisiia Tomanek” OSVČ.

DOI: $10.47451 /$ her2021-08-001

EOI: $10.11249 /$ her2021-08-001

The paper is published in Crossref, Internet Archive, Google Scholar, Academic Resource Index ResearchBib, JGate, ISI, CiteFactor, ICI, eLibrary databases.

Sergey $V$. Lebedev

Full Professor, Dr of Philosophical Sciences Head of the Department of philosophy Higher School of Folk Arts (Academy)

St Petersburg, Russia

E-mail: servicleb@list.ru

ORCID: 0000-0002-7994-2660

\title{
Cultural heritage protection in the globalization context
}

\section{Abstract:}

The article actualizes the problem of national identity through the preservation of the basis of the cultural heritage of peoples and ethnic groups in the era of globalization and the emergence of a large number of 'melting pots' that erase the edges of the uniqueness of individual peoples of the world. The author argues that for any emerging nation, the cultural heritage, even if artificial, determines to a large extent the 'core culture' and is one of the basic foundations of national identity. Consequently, an important role is played by the adaptation of immigrants, who bring and lobby their culture and traditions in new territories for themselves. It forces some countries seeking to preserve their history and cultural heritage to actively hinder the immigration process, even sacrificing the development of their ethnic group, which does not tend to reduce the birth rate. However, on other way, multiculturalism only contributes to the rooting of specific customs and traditions among immigrant diasporas, which finally turn into separate communities leading to a close existence. The author concludes that in conditions, when one's cultural heritage is withering and the core culture is disintegrating, new cultural values belonging to new minorities begin to arise.

Keywords:

national identity, cultural heritage, melting pot, globalization, culture, traditions, immigration.

Сергей Викторович Аебедев профессор, Аоктор философских наук заведующий кафедры философии Высшая школа народных искусств (Академия) Санкт-Петербург, Россия E-mail: servicleb@list.ru 
ORCID: 0000-0002-7994-2660

\section{Защита кумьтурного наследия в условиях глобализации}

\section{Aннотачия:}

В статье актуализируется проблема национальной илентичности через сохранение основ культурного наследия народов и этносов в эпоху глобализации и появления большого количества «плавильных котлов», которые стирают грани уникальности отдельных народов мира. Автор утвержАает, что Аля мюбой становящейся нации культурное наследие, пусть Ааже и искусственное, определяет в значительной степени «стержневую культуру» и яв яется одним из базовых основ национальной идентичности. В связи с этим, большую роль играет аАаптация иммигрантов, которые привносят и Аоббируют на новых Аля себя территориях собственную культуру и традиции, что вынужАает некоторые страны, стремящиеся сохранить свою историю и культурное наследие, активно препятствовать иммиграционному процессу, Ааже жертвуя развитием собственного этноса, который части имеет тенденции к сокращению рождаемости. ОАнако, с Аругой стороны, мультикультурализм мишь способствует укоренению особых обычаев и традиций у иммигрантских диаспор, которые окончательно превращаются в отдельные, ведущие сепаратное существование, общины. Автор делает вывоА, что в условиях, когАа увядает свое культурное наследие и распадается стержневая культура, начинают возникать новые культурные ценности, принаАлежащие уже новым меньшинствам.

Kлючевые слова:

национальная илентичность, культурное наследие, плавильный котёл, глобализация, культура, традиции, иммиграция.

1.

One of the 'eternal' and ever topical problems of scientific thought is the problem to preserve cultural heritage. We can actually understand what the 'present' is only by comparing what was inherent in our ancestors. In general, we can assume that the cultural heritage is the totality of all the cultural achievements of society, both tangible and spiritual, and also, the historical society experience, which has been deposited and forever fixed in the national memory. According to modern researchers, it is "based on achievements of various ages, passing to new generations in new epochs" (Dobrynin, 2012). Most often, cultural heritage refers to ancient architectural monuments of the past, historical ruins, glorious military victories and the work of great poets, writers and composers.

Any country and people stand on a certain national identity based on religion, language, historical memory, historical traditions, and finally, on folklore and folk art. In other words, a person, who feels himself, e.g., a Frenchman, should not only speak and think in French. For him, the historical traditions of ancient epics, the memory 
of great ancestors (Joan of Arc, ancient kings, leaders of the French Revolution, heroes of the Resistance, great poets, writers and composers) should be sacred. At the same time, such elements of cultural heritage as folk cuisine and ancient costumes play an equally important role.

For countries and peoples experiencing problems with identity, it is the cultural heritage that largely underlies self-awareness. No less important part of the cultural heritage of any ethnic group is also the historical tradition, which has become an integral part of the national cultural heritage. However, at the same time, it is a fairly new, artificially created tradition. Indeed, the historical tradition that has become part of the national identity is often reduced to the glorification of the exploits of the ancestors (which are extremely exaggerated or even invented much later), or to the 'primordial' rituals, customs and holidays created historically quite recently. At the same time, small ethnic groups that are just becoming nations have a specific need for the great traditions of the past. It is precisely to feel like 'small but proud' nations that the intellectual elite of these ethnic groups, especially, suffering from the complex of 'ancient civilization', is trying to create the heritage of their ancestors.

They are desperately trying to find in the past some evidence of the great kings and conquerors, also as ancient ruins that symbolize the glorious past, leftover from their ancestors. At the worst, if there were no medieval kings in history, there were no ancient ruins left, the language and ancient folklore traditions can form the basis of identity. The publication of the Finnish epic Kalevala by a Russian officer of Swedish origin Elias Lenrot in 1835 played a huge role in the formation of the Finns as a nation. In principle, Kalevala was an author's work based on ancient legends. However, the source of Lenroth's poetic inspiration was still the Finnish folk epic. So, the Finns, who did not have a great past, found the basis of national identity.

For the Baltic nations, Estonians and Latvians, the creativity of national poets played a similar role. Thanks to Friedrich Kreutzwald, who published the poem Kalevipoeg (son of Kalev), Estonians found a similar national epic. The publication of Kalevipoeg caused not so much literary as political disputes. Many critics denied the nationality and originality of the work, emphasizing that it is the author's poem of one person and does not have high literary qualities. The Estonian intelligentsia strongly emphasized the antiquity of the Kalevipoeg and found many artistic advantages in it, comparing it with the Iliad. However, by the beginning of the 20th century, Kalevipoeg was accepted as a great folk epic, which still lies at the heart of Estonian identity. Many reworked motifs have entered the oral tradition of Estonians and, thus, Kalevipoeg has become a folk epic. 
Similarly, the image of the hero Lachplesis (Lāčplēsis, translated as tearing a bear) plays in the Latvian self-consciousness. There is a holiday of Lachplesis and an order named after him. The image of Lachplesis is also the work of one author, but now it has become part of the national worldview. In 1888, Russian army staff captain, participant of the Russian-Turkish war of 1877-78, Andrey Pumpur based on folk legends, created the poem Lachplesis.

In addition to oral folklore (even if created by professional writers), national clothing plays a significant role in identity, especially when emphasizing its 'specialness' in front of strangers. And again, the 'original' outfit is very late in the historical sense quite often. It is necessary to give an example of the kilt history (a men's skirt, which is the most important element of the Scots' identity). Historically, the Scots, who did not yet form a single nation until the 19th century, were divided into numerous clans, English-speaking plainsmen (Lowlanders), and Celtic-speaking Highlanders (Highlanders), also as professing various Protestantism branches. And they did not wear a kilt. After the Scottish king became the king of England in 1603 (e.g., it was Scotland that annexed England, and not vice versa), the Scots experienced a certain identity crisis. On one way, they were part of the British elite, giving the British Empire many administrators, generals, travellers, businessmen, and scientists. However, on other way, the Scots were increasingly losing their distinct features from the English. Such outstanding Scots of the 18th century, as the founding father of classical economics Adam Smith and the prominent idealist philosopher David Hume, felt themselves to be English. Following the intellectual elite, ordinary Scots began to join the ranks of the English. The processes among the Highlanders, who were increasingly losing their Celtic language and customs, were especially significant.

In such conditions, there was an urgent need to create something native, ancient and different. As the contemporary researcher Hugh Trevor-Roper notes, "The creation of an independent 'Highland tradition' and the transfer of this new tradition, with its identification marks on all the Scots, was the work of the late 18th and early 19th century" (Trevor-Roper, 2015). Initially, the ancient poetry of the Celts was 'discovered'. Thus, the activity of the poet and forger James MacPherson, who allegedly discovered and translated the ancient Celtic bard Ossian legends in 176063, played a significant role in the formation of not only Scottish culture but also the literature of Romanticism in Europe. The result was the emergence of a whole literary 'Ossianism' that influenced European literature until almost the mid-19th century. However, 'Ossian' played a much significant role in the development of the self-consciousness of the Scots. As Trevor-Roper notes, "Previously equally despised 
by the lowland Scots as violent savages, and the Irish as illiterate poor relatives, they were now accepted by the whole of Europe as Kulturvolk, a people, who at the very time when England and Ireland were plunged into primitive barbarism, had already advanced from their ranks an epic poet of exquisite refinement, equal to Homer or even superior to him" (Trevor-Roper, 2015). Since Ossian supposedly lived in the 3rd century, the artists, who illustrated the texts of the Ossian cycle, depicted their hero in pseudo-romantic clothing, which unexpectedly took the form of a skirt.

A little earlier, the kilt concept appeared. In one of the Scotland descriptions, the 'quelt' was mentioned. As it is said quite definitely, it was not a separate outfit but simply a specific way of wearing "a plaid gathered in folds and belted at the waist to make a short skirt that covers the hips to half; the rest is thrown over the shoulders and fastened there... so, it turns out very similar to the poor London women, when they lift the hem of their dress over their heads wanting to hide from the rain" (Trevor-Roper, 2015). However, entrepreneurs paid attention to the kilt. A certain Englishman Rawlinson began to produce a kilt to save time and materials that could spend on making pants. The Rawlinson factory's products began to be purchased by the Scottish regiments of the British army. For convenience, kilts were divided by colour, depending on the clan, from which the soldiers, who made up the individual military units, came. In 1815, after the victory over Napoleon, Scottish regiments in kilts paraded through Paris. Thus, the outlook recognition of the kilt as a truly Scottish costume began.

Similarly, the Scottish national musical instrument, the bagpipe, was created. Strictly speaking, the bagpipe appeared in the 3rd millennium BC in the Middle East. However, in Europe, the bagpipe appeared only in the 13th century, originally in Spain. At the end of the next century, the bagpipe appeared in England. Among the Scots, bagpipes spread even later. However, due to circumstances, after the defeat of the 1745 uprising, bagpipes were banned by the British authorities. Of course, it was this circumstance that made the bagpipes popular among Scots. It is not surprising that in the next century, the bagpipe became an invariable attribute of the Scottish units of the British army.

Finally, there was also a 'truly Scottish' drink - whiskey. Strictly speaking, whiskey was first produced in Ireland where St Patrick, island Baptist, was considered the drink creator. However, at the beginning of the 19th century, the Scottish entrepreneur Robert Stein created an improved alembic and began to produce whiskey as a Scottish drink.

Nowadays, the very 'Scotland' concept is associated with kilt and whiskey. In all historical films about ancient Scotland, the characters wear skirts, play the 
bagpipes and drink whiskey, and also speak literary English. In present days, the Scottish identity is simply impossible without the kilt and whiskey, which historically have only recently appeared among the Scots. And thanks to them, the Scots from disparate clans and social groups turned into a nation with virile self-consciousness.

There are many similar examples. If the Scots had their state since the 9th century, then such an ancient people as the Basques, who never had the traditions of their statehood, had to compose their cultural heritage, as they say, completely. The Basques played a prominent role in the Spanish Reconquista. However, at the same time, the Basque identity was characterized by loyalty to the Catholic religion, Spanish monarchy and a close connection with its province (Asturias, Alava, Navarre, Biscay, Gipuzkoa). At the end of the century before last, a certain journalist Sabino Arana created the National Basque Party. However, for the party that declared itself the Basque people defender, the main difficulty was precisely the lack of a common Basque identity. And Arana began to invent a specific 'folk costume' and 'national traditions'. In his work on the need to Basque lands independence, Arana wrote about various ancient battles and the powerful leaders of his people. There was nothing like this in the ancient chronicles, but this did not bother the fanatics of the 'national idea' of the Basques. Arana learned the Basque language at an advanced age (a circumstance inherent in many figures of the nationalist movement at all times). Together with his brother Luis, Arana created the Basque flag. He also came up with his own name 'Euskadi' - the name for the entire territory of Spain and France, inhabited by the Basques. This fictional 'cultural heritage' formed the basis of Basque nationalism.

\section{2.}

As we can see, for any emerging nation, cultural heritage, even if artificial, is generally one of the basic foundations of national identity. It is the heritage that determines to a large extent the 'core culture'. As the famous American philosopher and sociologist Samuel Huntington wrote, "Most countries have a core, otherwise the main culture, a mainstream culture to which all or almost all members of this society are more or less committed. This national culture is usually supplemented by 'subordinate' cultures that exist at the level of subnational or, less often, transnational groups connected by religion, race or ethnicity, territory, class status - in a word, by what gives these people a sense of community. In America, subcultures have always been in abundance. In addition, it initially had a core Anglo-Protestant culture to which, despite numerous subcultures, the majority of the population was committed. 
For almost four centuries, this culture of the First settlers remained the main element of American identity" (Huntington, 2004).

At the same time, the arrival of many immigrants, who were distinguished by cultural diversity, although it generated many problems, still did not call into question the core culture foundations. The rapid adaptation of migrants (acculturation) was the reason for this. In the 19th and the first half of the 20th centuries, there were (and to some extent continue to exist) national immigrant neighbourhoods in the cities of the USA, Canada, Australia, Argentina, e.g., 'Little Italy', 'New Ireland', Jewish, Polish, Greek, Armenian, etc. In these quarters, the acculturation of immigrants and their descendants took place. They gradually joined the values of the core culture of their new homeland there. The very existence of such neighbourhoods, the presence of many fellow citizens with connections and influence in the new country helped to be integrated into the local culture without any specific psychological frustrations.

However, gradually, due to many circumstances, acculturation slowed down sharply, and the core culture ceased to be the basis of the identity of the inhabitants of the country. Accordingly, the original cultural values began to lose their significance. Now it makes no sense for immigrants, also as representatives of all other minorities, to join the local society by introducing them to the core culture. On the contrary, it is precisely belonging to minorities that contribute to raising the society's status. Therefore, it is necessary to demonstrate and preserve its differences from the core culture in every possible way.

The core culture erosion did not lead to mutual enrichment of cultures but to the formation of many minorities each of which has its private culture that is not closely connected with the cultures of other societies of the country. The weakening of the core culture ultimately led to a crisis of national identity. Political correctness, which prevents us from calling things by their proper names, does not allow us to objectively assess the society state.

As there were more and more newcomers, 'political correctness' and the policy of 'multiculturalism' began in the 'host countries'. However, it is precisely the argument about respect for all cultures without exception that is iron proof that Western cultural values are now being rejected by the 'new' inhabitants of Europe. It means that Western culture no longer impresses many residents of the West itself. Verbal arguments about 'minority rights', 'universal equality', 'respect for diversity', and other slogans used by Western politicians cannot hide the fact that in the West, they are simply trying to make a virtue out of need. 
However, when there are no spiritual bonds in a society, such a society crumbles. Nothing holds a country if there is no dominant core culture. When there is no common history, language, ethnic, and religious affiliation, then it is the fragmentation of society. Even now, in many Western countries, there is no nation. There is only various minorities' collection - racial, ethnic, confessional, gender, corporate, sexual. At the same time, there is no incentive to change anything in rich countries. However, a numerous young generation of 'coloured' citizens comes into life, ready to fight for the legacy of European civilization. They do not identify themselves with the residence country, also as with the historical homeland from which their parents came. At the same time, the "traditions of a large family that supports a patriarchal way of life, cultivating the customs of tribal solidarity, preserved among the descendants of immigrants, were sharply manifested in their way in the diaspora, which became a kind of meta-family and had its hierarchy" (Demintseva, 2008).

Until recently, sociology and political science in the West held optimistic views on the problems caused by mass immigration to Western countries. It was believed that gradually immigrants would be fully integrated into the local society, and all the problems generated by immigration were only temporary problems of 'growing' immigrants from backward agrarian regions into a modern industrial and postindustrial society. After all, this is exactly what happened in the United States and Canada with millions of immigrants from Italy, the Balkan and Eastern European countries, who differed in religion, language and culture from the Anglo-Protestant culture. The first generation of children of immigrants already born in the country have fully assimilated the core culture and have become 'one hundred per cent' Americans.

It would seem that the appearance of a significant middle class among British Indians, French Vietnamese, German Turks indicates the imminent 'infusion' of diasporas into local society. However, now the integration processes do not work. Multiculturalism only contributes to the rooting of specific customs and traditions among diasporas. As a result, diasporas finally turn into separate communities leading to a close existence. Paradoxically, middle class representatives from among the diaspora representatives, who are personally fully integrated into the country life, themselves construct and restore the 'ethnicity' of their fellow countrymen and tribesmen. The reason is obvious because diaspora members for these figures are voters, producers, and consumers.

Now, many 'new' Americans and Europeans, very numerous and rooted in Western countries, who continue to feel like strangers in this society, are united by 
new myths. For example, an exalted perception of the history of slavery or the colonial past of the historical homeland is very characteristic of representatives of ethnic minorities. The traditional religion in a fundamentalist wrapper, which sharply opposes its 'high morality' to the West, which has morally decomposed as a result of the 'sexual revolution', also unites minorities. And in these rapidly growing new racial, ethnic and confessional communities, their cultural heritage is gradually beginning to stand out. At the same time, the old core culture of Western countries is increasingly declining.

\section{3.}

For example, it is necessary to cite a prosperous country that has largely lost its identity - Canada. About this country, it was said that Canada has a lot of geographies but little history. Canada has always been a country of immigrants, and among the people, who moved to this sparsely populated British dominion, people of nonBritish origin predominated. Since the 1960s, most part of the immigrants in Canada has been non-Europeans, mostly of non-Christian faith, who grew up in a traditional tribal and clan society. At the same time, in Canada, unlike the United States, there was almost no 'melting pot', and the ethnic, racial and religious groups of the state did not merge into a single whole. It is significant that even during the 1991 census, only $2.8 \%$ of the country's residents called themselves simply 'Canadians'. The rest identified themselves as Canadians of British, French, German, Ukrainian and other origins. 26\% of Canadians are classified by statistics as 'other' (Golovkina, 2004).

And it is no coincidence that the multiculturalism concept was introduced into social philosophy by the already mentioned Canadian scientist Will Kimlichka, professor of political philosophy at Queens University. His book Multicultural Citizenship, published in 1995, remains one of the most fundamental and often cited works on the multiculturalism issue.

From a philosophical concept that denoted a mosaic multi-component society of the country, Canadian multiculturalism quickly turned into a practical policy. The Government of Canada was forced to react to the state transforming into a collection of various minorities. In 1971, the Government adopted a specific Act on Multiculturalism. To implement the Act decisions, a specific federal ministry was created with a large budget and a large staff of employees, and the Canadian Council for Multiculturalism was formed. The Act officially recognized 'cultural diversity' and committed to a policy of 'integration without assimilation' concerning minorities. The multicultural population of the country was recognized as a supra-ethnic civil community. The main multiculturalism feature was the recognition of the rights of 
collective subjects - ethnic, racial, socio-class, religious and cultural groups, including the ability to direct the education and upbringing of members of these groups. Currently, as noted by A. Cherkasov, a contemporary expert on the history and culture of the country, "Canada is a country of minorities connected by a national idea, ethnocultural groups, the majority of members of each of which considers themselves Canadians and at the same time proudly emphasizes their belonging to this ethnic group, without showing a conscious desire to assimilate with any other group" (Cherkasov, 2001). Thus, Canada can consider itself a country in which there is not and cannot be a state-forming nation. Accordingly, there is no defining core national culture. And there is almost no historical and cultural heritage.

Australia soon embarked on a similar policy. Until 1973, the authorities of the British dominion of Australia pursued a policy of 'White Australia'. Immigrants of non-European origin were not allowed into the country. Also, the indigenous inhabitants of the continent were aborigines. They were not considered citizens at all and not even counted in the population censuses. However, since the 1970s, restrictions on racial grounds have been lifted. So, the full openness of the country has been proclaimed. Currently, approximately $9 \%$ of Australians are of nonEuropean (mainly Asian) origin. It is significant that in Australia, social assistance is provided by the state not to immigrants in general, not to individuals, but certain ethnic groups.

In 1989, the Government adopted the National Multicultural Australia Programme, which guaranteed all citizens, regardless of racial, ethnic, gender and other preferences, free cultural realization in conditions of social guarantees of equality.

In the United States, the 'melting pot' that processed multilingual immigrants into a single nation stopped working already in the middle of the last century. The movement for the rights of the black population, which was subjected to severe discrimination until the 1960 s, ended not only with the granting of equal rights to them but also with the granting of a certain status to the black population as an independent subject of cultural and social life, having its privileges. It already emphasized the 'specialness' of the African-American population. At the same time, the previous racist restrictions on immigration to the United States were lifted. In 1965, President Lyndon Johnson signed a new immigration law in a theatrical setting, right on the steps of the Statue of Liberty. This law opened the way to the United States for representatives of all races, ethnic groups and faiths. At the same time, based on many laws and regulations adopted in the United States in the 1960-70 years, all immigrants (with very rare exceptions) were fully covered by civil rights, social benefits and benefits. These laws, adopted from the noblest motives, also had 
a downside: now immigrants did not have to look for a profession and a job in the United States at all. The most important thing was that now the immigrants, who settled in the country, had no reason to strive to integrate into American society. Significantly, immigration to the United States from Mexico (and Mexico is the general supplier of immigrants to the United States) is mainly immigration based on family ties (88\%), and immigration based on employment is 12\% (Bureiko, 2014). In other words, almost nine-tenths of Mexicans, who move to the United States, go on a call from relatives, who have already lived there and do not set themselves the task of getting a job and joining American society.

The results were not slow to affect as a giant immigration wave from all countries. At the same time, Europeans are an inconspicuous minority in this wave. The reasons are clear - Europe has long since exhausted its emigration potential and has itself become the second most important centre for the immigrants' influx from the most exotic regions of the world. The 2015 academic year was the first year in the United States history when the number of 'coloured' students in schools at all levels exceeded the number of students of European origin.

4.

However, Canada, Australia, and the United States are historically very young countries that originally emerged as immigrant' countries. However, countries with a truly great past, brilliant culture, and strong self-awareness are also gradually losing their identity based on cultural heritage.

However, since the second half of the 20th century, the leading European countries, such as Great Britain, France, Germany, Sweden, the Netherlands, etc., which experienced a massive influx of immigrants from former colonial countries, also switched to political multiculturalism. When large-scale labour immigration to Europe from developing countries only began in the 1960s, most leaders of Western European states proceeded from the fact that this immigration is a temporary phenomenon. Therefore, foreign workers themselves are some shift workers, who work several shifts and then return to their native land. It is significant that in German-language literature, foreign workers were called guest workers (from the German 'guest workers' - Gastarbeiter). From the German language, this concept has entered many European languages, including Russian. Politicians of Western European states believed that the 'guests-workers', having worked out the period prescribed by the labour contract, having received honestly earned money, would return home, and new ones would come in their place, also for a while. Because of this, the official authorities of European countries preferred not to educate guest 
workers and did not try to integrate them into local life. However, in the conditions of the demographic crisis in Europe, also as the reluctance of many local residents to work in 'dirty' and dangerous industries, guest workers have become a constant factor in economic development. They stayed in Europe for decades, began to call their relatives and friends (as a rule, very numerous). In 2013, the total number of international migrants amounted to 232 million people of which $31.3 \%$ were in the EU countries. In 2019, the number of international migrants reached 261 million, of which 84 million lived in Europe, 59 million in the United States and Canada (United Nations, Department of Economic and Social Affairs. Population Division, 2019).

Since the vast labour immigrants' majority have always been young people, moreover, who came from countries with the traditions of having many children, it is not surprising that in a short time it was immigrants, who began to provide almost all the natural population growth in many European countries. In general, in the leading countries of Western Europe (France, Germany, Belgium, etc.), the alien population makes up to $20 \%$ of all residents. In many major European cities (such as London, Paris, Frankfurt am Main, Brussels, Antwerp, etc.), indigenous Europeans have become an ethnic minority.

As in the United States, large-scale social and cultural changes have also taken place in European countries over the past half-century, which resulted in the fragmentation of European countries into many different minorities. Under such conditions, Western European leaders were forced to put multiculturalism at the basis of politics and countries of Western Europe with a thousand-year history and culture. Almost all the leading European countries have adopted specific laws on the equality of all cultures and implemented legislative measures' systems aimed to support ethnic minorities. In addition, the legislation of most EU countries prohibited any form of discrimination on ethnic, religious or racial signs.

Systems of measures aimed at supporting ethnic minorities have been developed in European countries. Gradually, the very concept of a 'national state' began to be abandoned in Europe. For example, Germany, which traditionally called itself a 'national state' (Nationalstaat), is now considered an 'immigration country' (Einwanderungstaat).

However, there are two sides to every coin. Multiculturalism at the state level began to turn into a very rigid imposition of its identity on each of the groups in practice, as opposed to the core culture of the majority. This led to real racial and ethnic segregation. In many cities of the leading countries of the West, completely closed settlements and urban quarters have appeared. Counter-societies have developed there with their schools, clubs, newspapers, cable TV, many social media 
sites and churches of all faiths. Since the middle of the last century, the immigrant quarters of European cities have developed their 'ethnic economy'. It is the name of an economic system in which the producer, advertiser, seller and consumer belong to the same ethnic group, racial-ethnic or confessional group that are not indigenous to this country. At the same time, practically nothing comes to the state budget from this 'ethnic economy'. In this counter-society, the whole life of a person can take place almost without intersecting with the local society. People are born in their ethnic hospitals, study in their schools, visit their doctors, buy from their sellers, marry representatives of their clan or caste, celebrate their ethnic (and sometimes tribal) holidays, and even find their last refuge in their cemeteries.

Alternative administrative institutions, almost unrelated to the official state authorities of the country, were formed there by a turnout order. The power over the residents of the neighbourhoods no longer belongs to elected municipal figures and mayors, but to 'respected people', among whom there may be tribal leaders, spiritual authorities, and often also leaders of the local ethnic mafia. Legal and illegal structures of such a counter-society effectively neutralize the activities of state authorities at the district level, turning them into purely decorative bodies that do not have real power. In such conditions, the protection of human rights is practically impossible. At the same time, self-defence detachments even appeared in many such quarters to 'protect' from right-wing radicals and police arbitrariness. Since the 1970s, there have been periodic riots in the immigrant quarters of European cities. In France, in October-November 2005, riots ('revolution of the suburbs') covered the whole country (Shmerlina, 2006). In August 2011, mass riots swept many cities in England, two years later in Sweden.

The main rioters' demands were reduced to one thing - let the police and representatives of the official authorities not enter our neighbourhoods, because our power is there! Thus, the state is gradually losing its sovereignty over the blocks in which hundreds of thousands of people live together.

As a result, the former society from which the parents of the immigrants came is artificially preserved in these closed quarters. And this society not only preserves but also constantly reproduces its original culture.

In the immigrant quarters, there was "duplication of all institutions: post offices, leisure centres, shops, sports grounds, bus stops, letterboxes... bus routes become tortuous to pass only through 'one-colour' neighbourhoods." (Demidov, 2013)

As a practical politician, former French President V. Giscard d'Estaing, based on his extensive experience, recognized, "when the share of immigrants in the population reaches a certain level, their desire to integrate into this population 
weakens, and after crossing a certain threshold, this desire changes to the opposite. And then the newcomers tend to group themselves, lock themselves in their environment and protect their original identity, preserving their language, their culture, all the old habits of everyday life. From this moment on, the integration process is suspended." (Giscard d'Estaing, 2004)

It has led to many negative consequences. There has been a deep erosion of the general institutions and communities - the national state, religion and the family. There was also a blurring of the boundaries of gender, race, and ethnicity. Economic and class macro-contradictions have been replaced by countless micro-conflicts of identities-gender, racial, confessional, subcultural, etc. In such conditions, the cultural heritage also loses its significance.

Here are some concrete examples from the state of Great Britain, which is experiencing an identity crisis, undermining the core culture and forgetting the cultural heritage of the past.

The United Kingdom, which until the second half of the 20th century did not belong to immigration countries (in the ordinary consciousness of ordinary Englishmen, Britain is still considered only the country of the British), also became the centre of attraction for immigrants from all over the former British Empire. When Britain turned into one of the most 'capacious' countries in terms of immigrants, who arrived (in terms of the proportion of people born abroad and permanently residing in the country, the UK surpassed the United States, and is second only to Australia and Israel), the authorities had to attend to the problem of integrating 'new Britons' into society. It is very significant that the second most popular name, which was received by male babies born in the British Isles in 2006, was the name Mohammed.

At the same time, the British authorities suppressed any manifestations of discontent among white Britons with the massive influx of immigrants into the country. Accusations of racial intolerance have become widely used against all native British citizens, who speak out against multiculturalism. However, at the same time, the authorities of the United Kingdom most often did not respond to the threatening sentiments from radical immigrants, who created 'Sharia zones' and 'territories free of white people' in British cities.

5.

However, if immigrants were a permanent element of society in these countries, then the 'world cultural revolution', which began with the student riots of 1968, became a specific character for the social and cultural development of the United 
States and several other countries. Unlike the 'revolution' of the same name in China, the Western revolution can be considered victorious. After the 1968 events, the leading Western establishment managed to neutralize the revolt of outsiders of the system, turning it into a game. The social protest was skillfully transferred to create many constantly changing youth subcultures, show business, pop art, etc. The movement for women's rights degenerated into a feminist movement, instantly divided into many directions. Many feminist terms, such as 'gender' (social gender), 'feminative' (feminine nouns denoting women, formed from the same-root masculine nouns), 'sexism' (gender discrimination), etc., have become common since that time. The protest of a part of the politically active society was also transferred from the real world to the dream world with the help of drugs. Thanks to the planting of a wide variety of religious and mystical cults, the considerable society's part interests were switched from changing reality to questions of the 'next life'. Various social movements, such as the movement to protect the environment, have become not just mass but have also turned into peculiar subcultures. The results of this were to create a kind of 'cultural ghettos' consisting of representatives of a wide variety of subcultures.

At the same time, successive 'reforms' of education began in the West, when the primitivization of education began to be introduced under the guise of 'democratization', 'political correctness' and the 'diversity' promotion. Over the past half-century, three generations of people have grown up in the West, not stupid and quite educated in their way. They are excellent narrow specialists in certain areas. But they have a very mosaic, devoid of integrity, idea of the world and humanity.

Thus, in the policy of multiculturalism, one can see the desire of the authorities of Western states to create a certain mechanism for stabilizing a multi-ethnic multicomponent society. It requires the preservation and further development of the cultural diversity of Western societies based on equal rights of both the majority and racial, ethnic and cultural minorities.

Almost all existing theories of multiculturalism recognize that all cultures are equal. Consequently, the national majority should not establish its cultural values as general and obligatory for everyone. The majority should not promote any culture as a core one, which all minorities should accept as their own. And, based on these provisions, the policy in the field of education is implemented.

Measures to establish 'positive discrimination' or 'affirmative action' have become an integral part of the multiculturalism policy. It is the measures aimed at eliminating the consequences of all types of discrimination in hiring or studying. The main goal of this policy is that groups of people, who were previously discriminated 
against (women, African Americans, Indians, homosexuals, disabled people), should now be given additional rights and benefits comparing representatives of the majority. For example, in most Western countries, minorities have quotas to enter state universities and the civil service. Additional opportunities should be provided to study and work, move up the career ladder, receive a specific salary supplement, etc. However, the result was a restriction of the rights of the majority.

In Europe, the ideas of positive discrimination have spread not only in the form of protection of national minorities but also providing preferences based on gender, protecting women's equality in rights with men, preventing the infringement of representatives of the LGBT community in all spheres (Kamenkova \& Murashko, 2006).

Following the creation of specific benefits, a series of public repentance for past sins towards minorities began, automatically involving the payment of monetary compensation to minorities.

The creation of a quota system for representatives of minorities could not but affect both politics and business. So, on December 1, 2020, one of the leading American stock exchanges - Nasdaq-launched an initiative to "establish greater diversity and equality in the management of companies whose securities are listed on the exchange". According to the Nasdaq proposal, listed companies should have at least one woman on their boards of directors in addition to the director from underrepresented minorities or a lesbian, gay, bisexual or transgender person. Foreign and medium-sized companies may limit the introduction of two women to the board of directors. Proponents of this approach note, "Their [minority] values will increasingly determine the market and the economy as a whole." (Nasdaq Defends Its New Diversity Mandate, 2020)

However, the greatest danger from positive discrimination was the crisis of the education system in many Western countries. The promotion of cultural diversity has led to implementing educational reforms in most Western countries - a total revision of school and university disciplines in philosophy, history, and culture. Now, it was necessary to reflect the historical and cultural contribution of all racial and ethnic groups and minorities, study their ethnocultural heritage.

According to researchers of national problems of the United States, I.A. Geevsky, S.A. Chervonnaya, "back in 1972, Congress passed a law on the study of the ethnic heritage of the US population. This law provided for the allocation of federal funds to establish ethnic studies faculties in higher educational institutions, also as the introduction of appropriate courses and programs in secondary educational institutions. By the beginning of the 80s, 250 specific courses on the 
study of the historical and cultural heritage of African Americans were operating in colleges and universities in the United States; numerous programs for studying the history and culture of Mexican Americans, Indians, Asian, Arab, and European ethnic groups. Special centres, faculties or departments of ethnic studies have appeared in several educational institutions." (Geevsky, Chervonnaya, 1985) In the new century, there can hardly be a higher educational institution without similar faculties and departments.

These 'positive actions' included a departure from monolingualism, recognition of the multilingualism concept, which allowed representatives of ethnic and racial minorities to use their native language in education and public and political life. In the United States, where a significant mass of residents are 'Latinos' or, more politically correct, Hispanic ('Spaniards', that is, more correctly, 'Hispanics'), there is a further spread and popularization of the Spanish language. It is also facilitated by the American media: the functioning of hundreds of federal and regional TV channels and radio stations with programs in Spanish, publication of more than 200 newspapers and 150 magazines (Garmash, 2010). In general, if current trends continue, by the middle of the 21 st century, at least $60 \%$ of the US population will speak Spanish, according to experts.

When receiving an education with specific privileges for minorities, the overall level of academic performance decreases. The reason for this is not only that minorities' representatives are poorer due to historical 'oppression'. To a large extent, representatives of minorities lose the incentive to study well at all. In favour of minorities, the requirements for students have been significantly relaxed. As a result, schools produce a significant mass of people with inflated ambitions and lack of some qualifications. The requirement to maintain political correctness leads to the overflow of humanitarian disciplines with specific disciplines on Gender Theories and History of the LGBT Community.

The prominent American economist and sociologist Paul Craig Roberts, a former assistant for economic policy to the US Secretary of the Treasury, editor of the most important business newspaper The Wall Street Journal, noted, “...Antiwhite indoctrination (systemic racism), which is the main function of American university education, penetrates secondary and elementary schools. The United States is probably the first country that uses education to destroy its future. Of course, the United States is the first country that made multicultural existence impossible. The identity politics of the liberal-progressive-left divides the country into hostile identity groups, some of which successfully cultivate victim status, which they use to suppress those, who do not have it, primarily heterosexual white men. 
The anti-American, anti-white liberal-progressive left has succeeded in brainwashing a significant part of the American youth. In America, the best students in the country are no longer excellent students. The best students are $\mathrm{C}$-students, who are distracted by indoctrination and just want to move on with their lives. It is the excellent students, who are susceptible to demonizing their country and themselves." (America Is a Dead Man Walking because American Youth, or Their Minds, Have Been Stolen, 2020)

The consequences of multiculturalism in the education sphere are manifested not only in the general decrease in the amount of knowledge received by students. Many representatives of minorities, even after receiving diplomas, do not have sufficient qualifications for further careers, because, in many respects, their academic success was only the result of various benefits and preferences for them as representatives of minorities. As a result, representatives of minorities do not get into the elite but remain members of one of the minority groups. As a result, the system of multiple coexistences of minorities continues to be reproduced.

\section{Conclusion}

At the conditions, when their cultural heritage is withering and the core culture is disintegrating, new cultural values belonging to new minorities are beginning to emerge.

There is also a certain danger that the authorities in some countries will start pedalling the theme of 'primordial traditions' with embroidered shirts, painted clay pots and folk dances in every possible way during the crisis. A classic example of this can be some post-Soviet countries, e.g., Ukraine or the Baltic republics. In the conditions, when industry and science have been eliminated in these countries, the leading elites are beginning to actively extol the 'spirituality' of the subordinate country people and invent the great antiquity together with 'folk culture', ranting that industry and science are not needed at all by the people with the richest inner world and singing songs.

However, in general, the modern world is characterized by a gradual rejection of its cultural values. The future belongs to those countries that protect and develop their cultural heritage and core culture. It would be better, if Russia is one of these countries. 


\section{References:}

America Is a Dead Man Walking because American Youth, or Their Minds, Have Been Stolen (2020, October 30). Retrieved June 20, 2021, from https://www.paulcraigroberts.org/2020/10/30/america-is-a-dead-manwalking-because-american-youth-or-their-minds-have-been-stolen/

Bureiko, N.N. (2014). Features of the ethnic immigration component to the United States in the late 20th and early 21st century. Studia Humanitatis, 1-2. (in Russian) Cherkasov, A. (2001, September 11). Ethnocultural mosaic and interethnic relations in Canada. Retrieved June 17, 2021, from http://www.niworld.ru/Statei/cherkasov/n1 (in Russian)

Demidov, A.M. (2013). Institutional reasons for the multiculturalism policy crisis in Europe. Young Scientist, 7 (54), 338-342. (in Russian)

Demintseva, E. (2008). To be an 'Arab' in France. Moscow: New Literary Review. (in Russian)

Dobrynin, D. S. (2012). The 'cultural heritage' concept in the Humanities. Bulletin of the Buryat State University, 6-1, 236-239. (in Russian)

Giscard d'Estaing, V. (2004). The French: Reflections on the fate of the people. Moscow: Ladomir. (in Russian)

Garmash, M.V. (2010). The Spanish-speaking world in the USA: the current state and prospects. Sociology of Power, 8, 97-103.

Geevsky, I.A., Chervonnaya, S.A. (1985). The national question in the social and political life of the United States. Moscow: Nauka. (in Russian)

Golovkina, O. V. (2004). Canadian multiculturalism as the basis of Canada's national identity. Bulletin of the Volgograd State University. Series 4: History. Regional Studies. International Relations, 9, 44-53. (in Russian)

Huntington, S. (2004). Who are we? Challenges to American national identity. Moscow: AST: Transitkniga. (in Russian)

Kamenkova, L.E., Murashko, L.O. (2006). Positive discrimination: concept, content, evolution. Journal of International Law and International Relations, 2, 3-7. (in Russian)

Nasdaq Defends Its New Diversity Mandate (2020, December 8). Retrieved July 12, 2021, from https://www.wsj.com/articles/nasdaq-defends-its-new-diversitymandate-11607464071

Shmerlina, I. (2006). Autumn riots in France: Russian focus of perception. Social Reality, 3, 42-52. (in Russian)

Trevor-Roper, H. (2015). Inventing a Tradition: The Highland Tradition of Scotland. Retrieved June 23, 2021, from https://intelros.ru/readroom/nz/nz62015/29057-izobretenie-tradicii-tradiciya-gorcev-shotlandii.html (in Russian) 
United Nations, Department of Economic and Social Affairs. Population Division (2019). International Migrant Stock 2019. 